\title{
Assessment of Diabetes Knowledge and its Associated Factors among Type 2 Diabetic Patients in Mekelle and Ayder Referral Hospitals, Ethiopia
}

Kalayou K Berhe ${ }^{*}$, Haftu B Gebru, Hailemariam B Kahsay and Alemseged A Kahsay

Department of Nursing, College of Health sciences,Mekelle University, Ethiopia

"Corresponding author: Kalayou K Berhe, Mekelle University, College of Health Sciences, Department of Nursing, PO. Box 1871, Tigray Region, Ethiopia, Tel: +251912117719; E-mail:Kalushaibex@yahoo.com

Rec date: Apr 21, 2014, Acc date: May 20, 2014, Pub date: May 25, 2014

Copyright: ( 2014 Berhe KK, et al. This is an open-access article distributed under the terms of the Creative Commons Attribution License, which permits unrestricted use, distribution, and reproduction in any medium, provided the original author and source are credited.

\begin{abstract}
Background: Poor patient understanding of diabetes is believed to impede appropriate self-care management, thus accelerating cardiovascular complications, stroke, and kidney failure.
\end{abstract}

Objective: To assess diabetes knowledge level and associated factors among type 2 diabetic patients in Mekelle hospital and Ayder referral hospitals, Mekelle City, Tigray, Northern Ethiopia.

Method: Institutional based cross sectional method was used and 310 study subjects was selected using systematic random sampling technique and the data was collected using interviewer administered structured questionnaire. Scoring method was employed to classify respondents' knowledge level.

Result: A total of 310 male and female adult type 2 diabetic patients were interviewed from the total of about 1000 diabetes patients who have regular follow up in the hospitals using standardized structured questionnaire and the response rate was $96.8 \%$. This study analyzed respondents' diabetes knowledge level and of the total only $44.0 \%$ of the respondents scored 'good' on the total diabetes knowledge questions. This result showed that there was significant association between diabetes family history and diabetes knowledge level $[P<0.025, A O R(95 \%$ $\mathrm{Cl})=1.860(1.077-3.209)]$.

Conclusion: Despite the important role of diabetes knowledge were recognized to be useful and effective in achieving diabetes control and preventing its serious complication, findings of this study confirm previous findings concerning the diabetes knowledge level. Generally diabetes knowledge level was suboptimal among type 2 diabetic patients in Ayder referral hospital endocrinology and Mekelle hospital chronic care unit.

Keywords: Type 2 diabetic patients; Diabetes knowledge; Diabetes management

\section{Introduction}

Diabetes is a general term for a group of metabolic disorders that affect the body's ability to process and use sugar (glucose) for energy. The prevalence of diabetes has reached epidemic proportions. World Health Organization predicts that developing countries will bear the brunt of this epidemic in the $21^{\text {st }}$ century. According to International Diabetes Federation (IDF) diabetes Atlas, 5 $5^{\text {th }}$ edition 2012 report, currently; more than $80 \%$ of people with diabetes live in Low and Middle Income Countries. An estimated 366 million people were living with diabetes in 2011. The number is expected to grow to 552 million by 2030 and the largest age group currently affected by diabetes is between $40-59$ years. The global prevalence of diabetes is $8.3 \%$. However, the African region is expected to experience the highest increase in coming years with estimated increase in prevalence rates of $98 \%$ for sub-Saharan Africa, and $94 \%$ for North Africa and the Middle East [1-4].

The IDF Atlas $5^{\text {th }}$ edition 2012 report revealed that in 2011, 14.7 million adults in the Africa region are estimated to have diabetes, with a regional prevalence of $3.8 \%$. This would rise to 28 million by 2030 with prevalence of $4.3 \%$, an increase of $80 \%$, as such exceeding the predicted worldwide increase of 55\%. Type 2 diabetes is responsible for $85-95 \%$ of all diabetes in high-income countries but Type 2 diabetes accounts for well over $90 \%$ of diabetes in Sub-Saharan Africa even in other low- and middle-income countries and population prevalence proportions ranged from $1 \%$ in rural Uganda to $12 \%$ in urban Kenya. Based on the IDF Atlas $5^{\text {th }}$ edition, 2012 report number of cases of diabetes in Ethiopia to be estimated about 1.4 million in $2011[5,6]$.

The greatest weapon in the fight against diabetes mellitus is knowledge. Information can help people assess their risk of diabetes, motivate them to seek proper treatment and care, and inspire them to take charge of their disease for their lifetime. In view of the increasingly high incidence of complications in diabetic patients, it would be valid to assess the perception of the primary healthcare patient of his or her actual disease state and the problems that may arise. Proper management requires life style changes and adequate Diabetes Knowledge of which is considered a key component of diabetes management. Differences in knowledge level have been described depending on level of education, gender and social classes. Assessment of the level of knowledge on diabetes among persons with diabetes can assist in targeting public health efforts to reduce diabetes related complications $[5,7-9]$. 
Today's nurse is faced with challenges of providing high quality evidence-based care to clients/patients in traditional as well as new innovative health care settings for both acute and chronic illnesses. A situation where diabetes patients visit clinics regularly and their blood glucose levels still remain high despite the treatment they receive is a problem that calls for attention. This is a very common observation in many diabetes patients. Sometimes, slight symptoms that these patients could take care of at home bring them back to the hospitals for medical checks. A good number of them, however, report to the hospital with severe complications, like gangrene that may lead to amputation and possible premature death, this might be because of lack of appropriate self care practices [10,11].

Furthermore, although the studies cited above have begun to illuminate our understanding of some of the predictors of differences in diabetes self-care, we currently lack an in-depth understanding or information of diabetes knowledge level and associated factors of type 2 diabetes patients especially this is more obviously true in Ethiopia, Mekelle Hospital and Ayder referral hospital. The major problematic condition about diabetes knowledge status is that there are limited research findings on patients who are found in sub Saharan Africa especially in Ethiopia, even there is no enough published material and little research is done. So the aim of this study was to assess knowledge level to diabetes and its associated factors in patients with type 2 diabetes who have follow up in Mekelle Hospital and Ayder referral hospital diabetes clinic, Mekelle City.

\section{Methods and Materials}

\section{Study setting, period and design}

Study area was Mekelle City it has two governmental and three privet hospitals. Ayder referral hospital was commenced its function in 2007 with 500 beds. The hospital is one of the major referral \& teaching hospital found in the region and the serves gives for patients from every corner of the region, some area of Afar and Amara regions with total annual flow of 32,000 patients. The second one is Mekelle Hospital, a Regional hospital for the area, that serve as a referral and teaching hospital, which was established in 1954 E.C with 162 beds and the total annual flow of 4276 patient. The study period was from Sep. 2012 to July 2013. The study design was institutional based crosssectional study design.

\section{Source population, study population and eligibility criteria}

The source population was all patients who visit the diabetes clinic of the hospitals during the study period. The study population was all Type 2 diabetic patients who visit the hospitals' diabetes clinic at the time of data collection period and fulfilling the inclusion criteria. Study subjects included in this study were those who were with age of greater than 18 years, diagnosed with type 2 diabetic and made follow up for at least one month. Study subjects excluded from this study were those who were unable to answer the questions because of impaired cognitive status.

\section{Sample size determination and sampling procedures}

The final sample size for this study was 310 . Proportion allocation was employed to allocate the sample size among the two hospitals. Systematic random sampling technique was utilized for this study.

\section{Data collection procedure and tool}

Data was collected using standardized structured questionnaire and three diploma completed Nurses with previous experience of data collection and multi lingual ability were recruited. Continuous follow up and supervision were made by the supervisors and principal investigators throughout the data collection period. Data collection was accomplished within twelve weeks duration (April $1^{\text {st }}$ week to July, 2013). Interviewer administered structured questionnaire data collection tool was used, it contains four parts, Part I was used to collect socio demographic data, part II was used to collect clinical status data of the study subjects, part III is DKQ (Diabetes Knowledge Questionnaire) which was used to measure the patients knowledge to diabetes. The DKQ was adopted contextually [12].

\section{Data quality assurance, entry and analysis}

To assure data quality, training and orientation was given for the data collectors by the principal investigators and the questionnaire was pre-tested prior to the actual data collection on 10 respondents outside study area and the respondents were excluded from the actual study. The questionnaire was initially prepared in English and then translated in to Tigrigna version. The Tigrigna version was again translated back to English to check for consistency of meaning. However since the dominant ethnic group is Tigrian with Tigrigna language then the study subjects was interviewed with Tigrigna version questionnaire. Moreover questionnaire was pre-tested and necessary corrections and amendment was considered. The collected data was reviewed and checked for completeness and consistency by principal investigators on daily bases at the spot during the data collection time. The data was recorded, cleaned and analyzed using Statistical package for social sciences (SPSS) version 16 software statistical packages. Frequencies and proportions were used to describe the study population in relation to relevant variables. Logistic regression was computed to assess statistical association viacalculating Crud Odds and Adjusted odds ratio to see the influence of independent variables on dependent variables, and significance of statistical association was assured or tested using 95\% confidence interval and P-value $(<0.05)$. Independent variables were Socio-demographic characteristics and Clinical or disease state and dependent variables were Diabetes knowledge level of the patients.

\section{Ethical consideration and operational definition}

Ethical clearance was secured from the Mekelle University, college of health science research review committee. Official letter of permissions was obtained from Tigray regional health Beauro, Ayder referral Hospital and Mekelle hospital medical director offices and respondents ware well informed about the purpose of the study, then information was collected after written consent from each participant was obtained. Information was recorded anonymously and confidentiality and beneficence were assured throughout the study period.

\section{Results}

\section{Socio-demographic characteristics of the respondents}

Of all respondents $173(57.7 \%)$ and $127(42.3 \%)$ were Male and Female respectively. The majority of the study participants $207(69 \%)$ were in the age group of 40 to 69 years. From the total respondents one hundred three $(34.3 \%)$ were unemployed and majority of the 
Citation: Berhe KK, Gebru HB, Kahsay HB, Kahsay AA (2014) Assessment of Diabetes Knowledge and its Associated Factors among Type 2

Page 3 of 7

study participants $171(57 \%)$ were had very low monthly income (Table 1).

\begin{tabular}{|c|c|c|c|c|}
\hline \multirow[t]{2}{*}{ Sr. No } & \multirow[t]{2}{*}{ Variable } & \multirow[t]{2}{*}{ Category } & \multicolumn{2}{|c|}{ Frequency } \\
\hline & & & NO & $\%$ \\
\hline \multirow[t]{2}{*}{1} & Gender & Female & 127 & 42.3 \\
\hline & & Male & 173 & 57.7 \\
\hline \multirow[t]{4}{*}{2} & Age $^{a}$ & $25-39$ years & 75 & 25.0 \\
\hline & & 40-54years & 110 & 36.7 \\
\hline & & $55-69$ years & 97 & 32.3 \\
\hline & & 70-84years & 18 & 6.0 \\
\hline \multirow[t]{4}{*}{3} & Monthly income ${ }^{b}$ & Very low & 171 & 57.0 \\
\hline & & Low & 66 & 22.0 \\
\hline & & Average & 41 & 13.7 \\
\hline & & Above average & 22 & 7.3 \\
\hline \multirow[t]{2}{*}{4} & Ethnicity & Tigrian & 286 & 95.3 \\
\hline & & Amara & 14 & 4.7 \\
\hline \multirow[t]{4}{*}{5} & Educational Level & Illiterate & 140 & 46.7 \\
\hline & & Elementary & 80 & 26.7 \\
\hline & & High school & 37 & 12.3 \\
\hline & & College university & 43 & 14.3 \\
\hline \multirow[t]{4}{*}{6} & Marital Status & Married & 220 & 73.3 \\
\hline & & Divorced & 10 & 3.3 \\
\hline & & Widowed & 7 & 2.3 \\
\hline & & Single/never married & 63 & 21.0 \\
\hline \multirow[t]{5}{*}{7} & Occupation & Employed & 87 & 29.0 \\
\hline & & un employed & 103 & 34.3 \\
\hline & & Merchant & 14 & 4.7 \\
\hline & & House servant & 70 & 23.3 \\
\hline & & Daily laborer & 26 & 8.7 \\
\hline \multirow[t]{2}{*}{8} & Religion & Orthodox Christian & 264 & 88.0 \\
\hline & & Muslim & 36 & 12.0 \\
\hline
\end{tabular}

Table 1: Socio demographic data of the respondents study done in Ayder referral and Mekelle hospitals, 2012/13 (N=300)

${ }^{a}$ Age category was adopted from research article ( study done in Africa) [19]

bMonthly income category: Very Low $<445$ Birr, Low=446-1200 Birr, Average $=1201-2500$ Birr, Above Average $=2501-3500$ Birr and High > 3501 Birr (Based on the Ethiopian Civil service monthly salary for civil servants)

\section{Health status data}

The mean age in which diabetic disease occurred was 44.53 with SD of \pm 11.07 years $[(95 \% \mathrm{CI})(33.46-55.60)]$ with minimum age of 27 and maximum age of 69 . The mean duration of diabetes was 5.63 with SD of \pm 7.6 years with minimum of 1 year and maximum of 33 years. More than half respondents 176 (58.7\%) had multiple injection treatment (two injections per day). Of all respondents $124(41.3 \%$ ) had oral hypoglycemic agent. Two hundred thirty two (77.3\%) of the respondents did not have family history of diabetes and only 44 (14.7\%) respondents had glucometre at home. Of all respondents, only $38(12.7 \%)$ had long term diabetic complication confirmed medically. Almost more than half of the respondents 168 (56\%) had poor knowledge about diabetes mellitus [13-19] (Table 2).

\begin{tabular}{|c|c|c|c|c|}
\hline \multirow[t]{2}{*}{ Sr. No } & \multirow[t]{2}{*}{ Variable } & \multirow[t]{2}{*}{ Category } & \multicolumn{2}{|c|}{ Frequency } \\
\hline & & & NO & $\%$ \\
\hline \multirow[t]{3}{*}{1} & \multirow{3}{*}{$\begin{array}{l}\text { Age in which diabetes } \\
\text { mellitus (DM) start }\end{array}$} & $25-39$ years & 114 & 38.0 \\
\hline & & $40-54$ years & 122 & 40.7 \\
\hline & & $55-69$ years & 64 & 21.3 \\
\hline \multirow[t]{3}{*}{2} & \multirow[t]{3}{*}{ Duration of DM } & less than 5 years & 207 & 69.0 \\
\hline & & $6-10$ years & 59 & 19.7 \\
\hline & & 11 and above years & 34 & 11.3 \\
\hline \multirow[t]{2}{*}{3} & \multirow[t]{2}{*}{ Family History of DM } & No & 232 & 77.3 \\
\hline & & Yes & 68 & 22.7 \\
\hline \multirow[t]{2}{*}{4} & \multirow[t]{2}{*}{ Treatment intensity } & $\begin{array}{l}\text { Oral hypoglycemic } \\
\text { agent }\end{array}$ & 124 & 41.3 \\
\hline & & Insulin therapy & 176 & 58.7 \\
\hline \multirow[t]{2}{*}{5} & \multirow{2}{*}{$\begin{array}{l}\text { Currently do you } \\
\text { haveglucometry at home }\end{array}$} & No & 256 & 85.3 \\
\hline & & Yes & 44 & 14.7 \\
\hline \multirow[t]{2}{*}{6} & \multirow{2}{*}{$\begin{array}{l}\text { Diabetes } \\
\text { Complication }\end{array}$} & No & 262 & 87.3 \\
\hline & & Yes & 38 & 12.7 \\
\hline \multirow[t]{2}{*}{7} & \multirow{2}{*}{$\begin{array}{l}\text { Diabetes knowledge } \\
\text { level }\end{array}$} & Poor Knowledge & 168 & 56.0 \\
\hline & & Good knowledge & 132 & 44.0 \\
\hline
\end{tabular}

Table 2: Health status and diabetes knowledge data of respondents study done in Ayder referral and Mekelle hospitals, 2012/13 ( $\mathrm{N}=300)$

\section{Diabetes knowledge level of respondents versus socio demographic and health related data}

Of the total only 132 (44.0\%) of the respondents scored 'good' on the total diabetes knowledge questions. There was association between monthly income $(\mathrm{P}=0.001)$, education $(\mathrm{P}<0.001)$ and occupation $(\mathrm{P}=0.02)$ with diabetes knowledge level but there was significant association with diabetes family history which means those respondents with diabetes family history were twice the chance of scoring good diabetes knowledge as compared with those without $[\mathrm{P}<0.025$, AOR $(95 \% \mathrm{CI})=1.860$ (1.077-3.209)], while no significant associations were found between diabetes knowledge and the 
Citation: Berhe KK, Gebru HB, Kahsay HB, Kahsay AA (2014) Assessment of Diabetes Knowledge and its Associated Factors among Type 2

Page 4 of 7

respondents' other demographic and diabetes-related characteristics (Table 3,4).

\begin{tabular}{|c|c|c|c|c|c|c|}
\hline \multirow[t]{2}{*}{ Factor } & \multicolumn{2}{|l|}{$\begin{array}{l}\text { Diabetes } \\
\text { level }\end{array}$} & \multirow[t]{2}{*}{ COR } & \multirow[t]{2}{*}{$\begin{array}{ll}\mathrm{Cl} & \text { of } \\
95 \% & \end{array}$} & \multirow[t]{2}{*}{ AOR } & \multirow[t]{2}{*}{$\begin{array}{l}\mathrm{Cl} \\
\text { of95\% }\end{array}$} \\
\hline & Poor & Good & & & & \\
\hline & No. (\%) & No. (\%) & & & & \\
\hline \multicolumn{7}{|c|}{ GenderP-value $=0.362$} \\
\hline Female & $75(25.0)$ & $52(17.3)$ & 1 & & & \\
\hline Male & $93(31.0)$ & $80(26.7)$ & 1.241 & $\begin{array}{l}(0.781-1 . \\
971)\end{array}$ & & \\
\hline Total & 168(56.0) & 132(44.0) & & & & \\
\hline \multicolumn{7}{|c|}{ Age $P$-value $=0.740$} \\
\hline 25-39years & $45(15.0)$ & $30(10.0)$ & 2.333 & $\begin{array}{l}(0.700-7 . \\
773)\end{array}$ & 1.735 & $\begin{array}{l}(0.469- \\
6.414)\end{array}$ \\
\hline 40-54years & $57(19.0)$ & $53(17.7)$ & 3.254 & $\begin{array}{l}(1.008-10 \\
.511)^{\star}\end{array}$ & 2.382 & $\begin{array}{l}(0.692- \\
8.196)\end{array}$ \\
\hline $55-69$ years & $52(17.3)$ & $45(15.0)$ & 3.029 & $\begin{array}{l}(0.930-9 . \\
864)\end{array}$ & 2.934 & $\begin{array}{l}(0.878- \\
9.801)\end{array}$ \\
\hline 70-84years & $14(4.7)$ & $4(1.3)$ & 1 & & 1 & \\
\hline Total & $168(56.0)$ & 132(44.0) & & & & \\
\hline \multicolumn{7}{|c|}{ Monthly incomeP-Value $=0.001$} \\
\hline Very low & 111(37.0) & $60(20.0)$ & 1 & & 0.793 & $\begin{array}{l}(0.242- \\
2.599)\end{array}$ \\
\hline Low & $32(10.7)$ & $34(11.3)$ & 1.966 & $\begin{array}{l}(1.105-3 \\
496)^{*}\end{array}$ & 1.277 & $\begin{array}{l}(0.394- \\
4.143)\end{array}$ \\
\hline Average & $15(5.0)$ & $26(8.7)$ & 3.207 & $\begin{array}{l}(1.578-6 \\
515)^{*}\end{array}$ & 1.515 & $\begin{array}{l}(0.510- \\
4.501)\end{array}$ \\
\hline $\begin{array}{l}\text { Above } \\
\text { average }\end{array}$ & $10(3.3)$ & $12(4.0)$ & 2.22 & $\begin{array}{l}(0.906-5 . \\
439)\end{array}$ & 1 & \\
\hline Total & $168(56.0)$ & $132(44.0)$ & & & & \\
\hline \multicolumn{7}{|c|}{ Level of educationP-Value $<0.001$} \\
\hline Illiterate & $92(30.7)$ & $48(16.0)$ & 1 & & 0.424 & $\begin{array}{l}(0.143- \\
1.256)\end{array}$ \\
\hline Elementary & $42(14.0)$ & $38(12.7)$ & 1.734 & $\begin{array}{l}(0.990-3 . \\
038)\end{array}$ & 0.608 & $\begin{array}{l}(0.218- \\
1.695)\end{array}$ \\
\hline High school & $19(6.3)$ & $18(6.0)$ & 1.816 & $\begin{array}{l}(0.872-3 \\
779)^{*}\end{array}$ & 0.612 & $\begin{array}{l}(0.215- \\
1.745)\end{array}$ \\
\hline $\begin{array}{l}\text { College } \\
\text { university }\end{array}$ & $15(5.0)$ & $28(9.3)$ & 3.578 & $\begin{array}{l}(1.746-7 \\
333)^{*}\end{array}$ & 1 & \\
\hline Total & $168(56.0)$ & $132(44.0)$ & & & & \\
\hline \multicolumn{7}{|c|}{ MaritalstatusP-Value $=0.725$} \\
\hline Married & $121(40.3)$ & 99(33.0) & 1.091 & $\begin{array}{l}(0.620-1 . \\
920)\end{array}$ & & \\
\hline Divorced & $7(2.3)$ & $3(1.0)$ & 0.571 & $\begin{array}{l}(0.135-2 . \\
416)\end{array}$ & & \\
\hline
\end{tabular}

\begin{tabular}{|l|l|l|l|l|l|l|}
\hline Widowed & $4(1.3)$ & $3(1.0)$ & 1 & $\begin{array}{l}(0.206-4 . \\
845)\end{array}$ & & \\
\hline $\begin{array}{l}\text { Single/never } \\
\text { married }\end{array}$ & $36(12.0)$ & $27(9.0)$ & 1 & & & \\
\hline Total & $168(56.0)$ & $132(44.0)$ & & & & \\
\hline Occupation:P-Value=0.002 & \multicolumn{7}{|l|}{} & \\
\hline Employed & $38(12.7)$ & $49(16.3)$ & 3.5 & $\begin{array}{l}(1.334-9 . \\
183)^{*}\end{array}$ & 1.536 & $\begin{array}{l}(0.485- \\
4.858)\end{array}$ \\
\hline un employed & $59(19.7)$ & $44(14.7)$ & 2.024 & $\begin{array}{l}(0.782-5 . \\
236)\end{array}$ & 1.803 & $\begin{array}{l}(0.682- \\
4.767)\end{array}$ \\
\hline Merchant & $6(2.0)$ & $8(2.7)$ & 3.619 & $\begin{array}{l}(0.921-14 \\
.214)\end{array}$ & 1.633 & $\begin{array}{l}(0.337- \\
7.906)\end{array}$ \\
\hline $\begin{array}{l}\text { House } \\
\text { servant }\end{array}$ & $46(15.3)$ & $24(8.0)$ & 1.416 & $\begin{array}{l}(0.522-3 . \\
839)\end{array}$ & 1.261 & $\begin{array}{l}(0.426- \\
3.731)\end{array}$ \\
\hline Daily laborer & $19(6.3)$ & $7(2.3)$ & 1 & & 1 & \\
\hline Total & $168(56.0)$ & $132(44.0)$ & & & & \\
\hline
\end{tabular}

Table 3: Logistic Regression Analysis result of Diabetes knowledge levelamong Type 2 diabetes study subjects in Mekelle \& Ayder hospital, Ethiopia 2012/13, (N=300)

${ }^{*}$ Statistically associated Variable, $\mathrm{P}=<0.05$, COR: Crud odds Ratio; AOR: Adjusted Odds Ratio

${ }^{\star}$ Variable were showed Statistical Association in COR but lost during AOR Analysis, NB: P-Value is, Value of COR analysis result

\begin{tabular}{|c|c|c|c|c|c|c|}
\hline \multirow[t]{2}{*}{ Variables } & \multicolumn{2}{|c|}{$\begin{array}{l}\text { Diabetes } \\
\text { knowledge level }\end{array}$} & \multirow[t]{2}{*}{ COR } & \multirow[t]{2}{*}{$\mathrm{Cl}$ of $95 \%$} & \multirow[t]{2}{*}{$\begin{array}{l}\text { AO } \\
\mathbf{R}\end{array}$} & \multirow[t]{2}{*}{$\mathrm{Cl}$ of $95 \%$} \\
\hline & Poor & Good & & & & \\
\hline & No. (\%) & No. (\%) & & & & \\
\hline \multicolumn{7}{|c|}{ Age in which diabetes startedP-value $=0.757$} \\
\hline 25-39years & $66(22.0)$ & $48(16.0)$ & 1.212 & $\begin{array}{l}(0.647-2.27 \\
\text { 1) }\end{array}$ & & \\
\hline 40-54years & $62(20.7)$ & $60(20.0)$ & 1.613 & $\begin{array}{l}\text { (0.869-2.99 } \\
\text { 3) }\end{array}$ & & \\
\hline $\begin{array}{l}55-69 \\
\text { years }\end{array}$ & $40(13.3)$ & $24(8.0)$ & 1 & & & \\
\hline Total & )$^{168(56.0}$ & )$^{132(44.0}$ & & & & \\
\hline \multicolumn{7}{|c|}{ Duration of diabetesP-Value $=\mathbf{0 . 2 4 4}$} \\
\hline $\begin{array}{l}\text { less than } 5 \\
\text { years }\end{array}$ & )$^{110(36.7}$ & $97(32.3)$ & 1.26 & $\begin{array}{l}(0.604-2.62 \\
9)\end{array}$ & & \\
\hline $6-10$ years & $38(12.7)$ & $21(7.0)$ & 0.789 & $\begin{array}{l}(0.332-1.87 \\
7)\end{array}$ & & \\
\hline $\begin{array}{l}11 \text { and } \\
\text { above } \\
\text { years }\end{array}$ & $20(6.7)$ & $14(4.7)$ & 1 & & & \\
\hline Total & $\begin{array}{l}168(56.0 \\
)^{-16}\end{array}$ & $\begin{array}{l}132(44.0 \\
)^{-1}\end{array}$ & & & & \\
\hline Family His & $y$ of dia & tesP-Valu & $=0.025$ & & & \\
\hline
\end{tabular}




\begin{tabular}{|c|c|c|c|c|c|c|}
\hline No & )$^{138(46.0}$ & $94(31.3)$ & 1 & & 1 & \\
\hline Yes & $30(10.0)$ & $38(12.7)$ & 1.86 & $\begin{array}{l}(1.077-3.20 \\
9)\end{array}$ & 1.86 & $\begin{array}{l}(1.077-3.209 \\
)^{\star *}\end{array}$ \\
\hline Total & )$^{168(56.0}$ & $\begin{array}{l}132(44.0 \\
)\end{array}$ & & & & \\
\hline
\end{tabular}

\begin{tabular}{|l|l|l|l|l|l|l|}
\hline \multicolumn{6}{|l|}{ Treatment intensityP-Value $=0.565$} \\
\hline $\begin{array}{l}\text { Oral } \\
\text { hypoglyce } \\
\text { mic agent }\end{array}$ & $67(22.3)$ & $57(19.0)$ & 1.146 & $\begin{array}{l}(0.721-1.82 \\
0)\end{array}$ & & \\
\hline $\begin{array}{l}\text { Insulin } \\
\text { therapy }\end{array}$ & $\begin{array}{l}101(33.7 \\
)\end{array}$ & $75(25.0)$ & 1 & & & \\
\hline Total & $168(56.0$ & $\begin{array}{l}132(44.0 \\
\text { ) }\end{array}$ & & & & \\
\hline
\end{tabular}

Presence of glucometryP-Value $=0.012$

\begin{tabular}{|l|l|l|l|l|l|l|}
\hline No & $\begin{array}{l}151(50.3 \\
\text { ) }\end{array}$ & $\begin{array}{l}105(35.0 \\
)\end{array}$ & 1 & & \\
\hline Yes & $17(5.7)$ & $27(9.0)$ & 2.284 & $\begin{array}{l}(1.185-4.40 \\
1)\end{array}$ & & \\
\hline Total & $\begin{array}{l}168(56.0 \\
)\end{array}$ & $\begin{array}{l}132(44.0 \\
)\end{array}$ & & & & \\
\hline
\end{tabular}

Diabetes ComplicationP-Value $=\mathbf{0 . 4 2 6}$

\begin{tabular}{|l|l|l|l|l|l|l|}
\hline No & $\begin{array}{l}149(49.7 \\
\text { ) }\end{array}$ & $\begin{array}{l}113(37.7 \\
)\end{array}$ & 1.319 & $\begin{array}{l}(0.667-2.60 \\
6)\end{array}$ & & \\
\hline Yes & $19(6.3)$ & $19(6.3)$ & 1 & & & \\
\hline Total & $\begin{array}{l}168(56.0 \\
)\end{array}$ & $\begin{array}{l}132(44.0 \\
)\end{array}$ & & & & \\
\hline
\end{tabular}

Table 4: Logistic Regression Analysis result of Diabetes knowledge level among Type 2 diabetes study subjects in Mekelle \& Ayder hospital, Ethiopia 2012/13,(N=300)

${ }^{*}$ Statistically associated Variable, $\mathrm{P}=<0.05$, COR: Crud odds Ratio; AOR: Adjusted Odds Ratio

${ }^{*}$ Variable were showed Statistical Association in COR but lost during AOR Analysis, NB: P-Value is, Value of COR analysis result

\section{Discussion}

In Ethiopia, there is limited information about the diabetes knowledge of patients with type 2 diabetes mellitus. Thus this study has tried to assess the diabetes knowledge level and associated factors among type 2 diabetes patients in Ayeder referral Hospital endocrinology unit and Mekelle Hospital chronic care unit, Mekelle City, Ethiopia. In this study $94.0 \%$ respondents were found to be in the age group of 25 to 69 years and $6.0 \%$ of the respondents were in the age group of 70-84 years. Similarly study done in Ethiopia (Tikur Anbesa specialized hospital), Egypt showed that $73 \%, 66 \%$ respondents were in the age group of 30-60 years and $28 \%, 44 \%$ of respondents were 61 and above years respectively [20-31].

Diabetes outcome depends mainly on the patient' sound knowledge of self-care and the disease that is dependent upon their knowledge of the disease, including health-related behaviour and care-seeking which are guided and determined by individually and culturally defined beliefs about health, illness and health-care. It is reported that patients with low diabetes knowledge levels are least likely to comply with diabetes management and instructions from health-care professionals. As far as we know, this is the first study investigating diabetes knowledge using a validated instrument among diabetes patients who have follow-up in Ayder referral hospital and Mekelle hospital. Overall, $96.0 \%$ of the respondents correctly answered the Diabetes knowledge questionnaire. In this study of adults with diabetes mellitus and having different types of treatment, the results showed that lower than half of $132(44.0 \%)$ respondents had good knowledge about diabetes this showed that the present study results were lower than study finding done in U.A.E $69 \%$ and higher than study done in Zimbabwe 20.7\% [32-39].

A study done in Ethiopia revealed that $93.7 \%$ of the respondents had general knowledge about diabetes. Multiple logistic-regression analyses were used to estimate the independent associations between poor knowledge and socio-demographic variables and diabetes-related characteristics accordingly no significant differences were detected in respondents' diabetes ' knowledge with one exception which is reporting family history of diabetes was significantly associated with knowledge $[\mathrm{P}<0.025$, AOR $(95 \% \quad \mathrm{CI})=1.860 \quad(1.077-3.209)]$, but significant association was obtained between respondents' age, monthly income, level of education and occupation and level of diabetes knowledge and lost during covariant analysis. Similarly a study done in China revealed that there was significant association of respondents' education level and family history of diabetes with diabetes knowledge and studies done in U.A.E and Zimbabwe indicated that there was significant association of respondents' attitude, diabetes complication and gender with their knowledge level $(\mathrm{r}=0.320, \mathrm{p}<0.001$ and $\mathrm{r}=0.270, \mathrm{p}<0.001)$ and $(\mathrm{OR}=3.5 ; 95 \% \mathrm{CI} 1.2-$ $10.6, \mathrm{p}=0.028, \mathrm{~b}=1.250)[20,30,33,40-49]$ respectively.

\section{Conclusion}

Despite the important role of diabetes knowledge in the management of diabetes were recognized to be useful and effective in achieving diabetes control and preventing its serious complication, findings of this study confirm previous findings concerning diabetes knowledge level among people living with type 2 diabetes: More than half number of the respondents score poor knowledge on diabetes and this were more problematic and This result also showed that there was significant association between diabetes family history and diabetes knowledge level. Generally diabetes knowledge level was sub-optimal among type 2 diabetic patients in Ayder referral hospital endocrinology and Mekelle hospital chronic care unit.

\section{Competing Interests}

In this manuscript there is no any competing interest declaration from anybody or organization about finance, and non financial competing interests such as political, personal, religious, ideological, academic, intellectual, commercial or any other.

\section{Acknowledgements}

Our deepest gratitude goes to Mekelle University, Department of Nursing for every help. And we would like to extend our sincere gratitude to the data collectors, supervisors and the study participants for being involved in the study. 


\section{References}

1. Diabetics (2011) Better medicine.

2. RomeshKhardori (2010) Type 2 Diabetes Mellitus Workup, Medscape.

3. Diabetic facts (2011) IDA data base.

4. $\quad$ Diabetes in the developing world (2011) Media Backgrounder IDF data base. http://www.worlddiabetesfoundation.org/media

5. Hall V, Thomsen RW, Henriksen O, Lohse N (2011) Diabetes in Sub Saharan Africa 1999-2011: epidemiology and public health implications. A systematic review. BMC Public Health 11: 564.

6. Moodley LM, Rambiritch V (2007) An assessment of the level of knowledge about diabetes mellitus among diabetic patients in a primary healthcare setting: SA FamPract 49: 16.

7. Al-Sarihin KK, Bani-Khaled MH, Haddad FH, Althwabia II (2012) Diabetes Knowledge among Patients with Diabetes Mellitus: JRMS 19: 72-77.

8. Feleke Y, Enquselassie F (2005) An assessment of the health care system for diabetes in Addis Ababa, Ethiopia. Ethiop J Health Dev 19: 203-210.

9. WHO (2011) Diabetes Fact sheet $\mathrm{N}^{\circ} 312$.

10. Uchenna OV, Ijeoma EO (2009) Knowledge of diabetes management and control by diabetic patients: International Journal of Medicine and Medical Sciences 1: 353-358.

11. Schoenberg NE, Drungle SC (2001) Barriers to non-insulin dependent diabetes mellitus (NIDDM) self-care practices among older women. J Aging Health 13: 443-466.

12. Patient's Diabetes Knowledge Questionnaire

13. Feleke Y (2004) Studies on Diabetes Mellitus and other Endocrine diseases in Addis Ababa, Ethiopia.

14. MirkaKneckt (2000) Psychological features characterizing oral health behavior, diabetes self-care health status among IDDM patients: Oulu University Library.

15. Eregie A, Unadike BC (2010) Factors associated with self-monitoring of glycaemic control among persons with diabetes in Benin City, Nigeria. African Journal of Diabetes Medicine 19: 1.

16. Mastura I, Mimi O, Piterman L, Teng CL, Wijesinha S (2007) Selfmonitoring of blood glucose among diabetes patients attending government health clinics. Med J Malaysia 62: 147-151.

17. Majra JP, Acharya D (2009) Awareness Regarding Self Care among Diabetics in Rural India. Middle East Journal of Medicine 7.

18. Tan MY, Magarey J (2008) Self-care practices of Malaysian adults with diabetes and sub-optimal glycaemic control. Patient EducCouns 72: 252-267.

19. Beckles GL, Engelgau MM, Narayan KM, Herman WH, Aubert RE, et al. (1998) Population-based assessment of the level of care among adults with diabetes in the U.S. Diabetes Care 21: 1432-1438.

20. Mahfouz EM, Awadalla HI (2011) Compliance to diabetes selfmanagement in rural El-Mina, Egypt. Cent Eur J Public Health 19: 35-41.

21. Yekta Z, Pourali R, Aghassi MR, Ashragh N, Ravanyar L, et al. (2011) Assessment of Self-Care Practice and Its Associated Factors among Diabetic Patients in Urban Area of Urmia, Northwest of Iran. J Res Health Sci 11: 33-38.

22. Yusuff KB, Obe O, Joseph BY (2008) Adherence to anti-diabetic drug therapy and self management practices among type-2 diabetics in Nigeria. Pharm World Sci 30: 876-883.

23. Toljamo M, Hentinen M (2001) Adherence to self-care and glycaemic control among people with insulin-dependent diabetes mellitus. J AdvNurs 34: 780-786.

24. Al-Kaabi J, Al-Maskari F, Saadi H, Afandi B, Parkar H, et al. (2008) Assessment of Dietary Practice Among Diabetic Patients in the United Arab Emirates. Rev Diabet Stud 110-115.

25. Ruggiero L, Glasgow R, Dryfoos JM, Rossi JS, Prochaska JO, et al. (1997) Diabetes self-management. Self-reported recommendations and patterns in a large population. Diabetes Care 20: 568-576.
26. Al-Kaabi J, Al-Maskari F, Saadi H, Afandi B, Parkar H, et al. (2009) Physical Activity and Reported Barriers to Activity among Type 2 Diabetic Patients in the United Arab Emirates. Rev Diabet Stud 6: 271-278.

27. Desalu OO, Salawu FK, Jimoh AK, Adekoya AO, Busari OA, et al. (2011) Diabetic foot care: self reported knowledge and practice among patients attending three tertiary hospital in Nigeria. Ghana Med J 45: 60-65.

28. Moreno Hernández MI, Trilla Soler M, EsplugaCapdevila A, Mengual Miralles N, BundóVidiella M, et al. (1997) [Self care and risk factors of diabetic foot in patients with type II diabetes mellitus]. AtenPrimaria 20: 185-190.

29. Hasnain S, Sheikh NH (2007) Knowledge and practices regarding foot care in diabetic patients visiting diabetic clinic in Jinnah Hospital, Lahore. J Pak Med Assoc 59: 687- 690.

30. Kidanu BK, Asrat D, Bayeray KA, Berhe GH (2012) Assesment of diabetes self-care practices and associated factors among type 2 diabetic patients in TikurAnbessa specialized hospital, Addis Ababa, Ethiopia. IJPSR 3: 4219.

31. Berhe KK, Kahsay AB, Gebru HB (2013) Assessment of Adherence to Diabetes Self-Management Practices among Type Ii Diabetic Patients in TikurAnbesa Hospital, Addis Ababa city, Ethiopia. Greener Journal of Medical Sciences 3: 211-221.

32. Shah VN, Kamdar PK, Shah N (2009) Assessing the knowledge, attitudes and practice of type 2 diabetes among patients of Saurashtra region, Gujarat. Int J Diabetes DevCtries 29: 118-122.

33. (2012) Diabetes self care. J ClinNurs 22: 51-60. [doi: 10.1111/j. 1365-2702.2012.04273.x.]

34. Al-Maskari F, El-Sadig M, Al-Kaabi JM, Afandi B, Nagelkerke N, et al. (2013) Knowledge, attitude and practices of diabetic patients in the United Arab Emirates. PLoS One 8: e52857.

35. Chan YM, Molassiotis A (1999) The relationship between diabetes knowledge and compliance among Chinese with non-insulin dependent diabetes mellitus in Hong Kong. J AdvNurs 30: 431-438.

36. Al-QazazHKh, Sulaiman SA, Hassali MA, Shafie AA, Sundram S, et al. (2011) Diabetes knowledge, medication adherence and glycemic control among patients with type 2 diabetes. Int J Clin Pharm 33: 1028-1035.

37. Esther Mufunda, Kerstin Wikby, Albin Björn, Katarina Hjelm (2012) Level and determinants of diabetes knowledge in patients with diabetes in Zimbabwe: a cross-sectional study. The Pan African Medical Journal 13: 78.

38. ShuHui Ng, KhengHooi Chan (2012) Knowledge, Attitude and Practice among Diabetic Patients in Monash University Sunway Campus, Malaysia : Abstracts of 5 th International Online Medical Conference (IOMC 2012)

39. Heather P. Whitley, Joli D. FERMO, Kelly RAGUCCI, Elinor C. CHUMNEY(2006) Pharmacy Practice (Granada) versión On-line ISSN 1885-642X Pharmacy pract. (Granada Ed. impr.) v.4 n.4 Redondelaoct.dic: http://dx.doi.org/10.4321/S1885-642X2006000400006 )

40. Kaur K, Singh MM, Kumar, Walia I (1998) Knowledge and self-care practices of diabetics in a resettlement colony of Chandigarh. Indian J Med Sci 52: 341-347.

41. Ayele K, Tesfa B, Abebe L, Tilahun T, Girma E (2012) Self-carebehavior among patients with diabetes in Harari, Eastern Ethiopia: the health belief model perspective. PLoS One 7: e35515.

42. Gul N (2010) Knowledge, attitudes and practices of type 2 diabetic patients. J Ayub Med Coll Abbottabad 22: 128-131.

43. Badruddin N, Basit A, Hydrie MZI, HakeemR (2002) Knowledge, Attitude and Practices of Patients Visiting a Diabetes Care Unit. Pakistan Journal of Nutrition 1:99-102.

44. Bloomgarden ZT (1998) Cardiac disease and related topics. American diabetes association annual meeting, 1998. Cardiac disease and related topics. Diabetes Care 21: 1764-1773.

45. Fawcett J (2008) Dorothea Orem's Self-Care Framework.

46. Dorothea Orem (2009) Orem's self-care framework. Taber's Cyclopedic Medical. 
Citation: Berhe KK, Gebru HB, Kahsay HB, Kahsay AA (2014) Assessment of Diabetes Knowledge and its Associated Factors among Type 2 Diabetic Patients in Mekelle and Ayder Referral Hospitals, Ethiopia . J Diabetes Metab 5: 378. doi:10.4172/2155-6156.1000378

Page 7 of 7

47. Orem (1993) D.E. Nursing: Concepts of practice 4th edition. St. Louis: Mosbly: 435.

48. Toobert DJ, Hampson SE, Glasgow RE (2000) The summary of diabetes self-care activities measure: results from 7 studies and a revised scale. Diabetes Care 23: 943-950.
49. Navaratne JT, Pushpa F (2000) Knowledge and self care practices of diabetic patients on oral hypoglycaemic drugs. Galle Medical Journal. http://hellis.srilanka.healthrepository.org/handle/123456789/6074 